\title{
Small Hydropower Development and Legal Limitations in Thailand
}

\author{
Thanaporn Supriyasilp ${ }^{1, *}$, Kobkiat Pongput ${ }^{2}$, Challenge Robkob ${ }^{3}$ \\ ${ }^{1}$ Department of Civil Engineering, Faculty of Engineering, Chiang Mai University. Thailand. 50200. \\ Science and Technology Research Institute, Chiang Mai University. Thailand. 50200. \\ ${ }^{2}$ Water Resources Engineering Department of Kasetsart University, Bangkhen, Bangkok, Thailand. 10900. \\ ${ }^{3}$ Biodiversity-based Economy Development Office (Public Organization), Laksi, Bangkok, Thailand. 10210. \\ * Corresponding author. Tel: +66 53942461, Fax: +66 53942478, E-mail: thanaporn@eng.cmu.ac.th,
} istdir@chiangmai.ac.th

\begin{abstract}
The northern region of Thailand which consists of the Ping, Wang, Yom, and Nan river basins has potential for small hydropower development. The Ping and Wang River Basins are used as case studies. Apart from technical aspects such as electricity generation, engineering and economic aspects, the socio-economics, environment, law and regulation, and stakeholder involvement aspects are also taking into consideration. There are 64 potential projects in the Ping River Basin. The overall electricity potential is about 211 MW with annual power generation of about $720 \mathrm{GWh}$. For the Wang River Basin, there are 19 potential projects with about 6 MW and an annual power generation of about $30 \mathrm{GWh}$. However, most of these potential projects are located in forested areas with legal limitations. The various types of forests can result in different levels of legal obstacles. Therefore, the procedure required for permission is varied and is dependent on both the desired development and the forest in question. The laws and regulations related to project development in forested areas are reviewed and are summarized on a case by case basis in a way that is easily understood and accessible for others to use as a reference for other areas. The suggestions for policy adjustments with environmental friendly consideration are also discussed.
\end{abstract}

Keywords: Hydropower development, legal limitations, forested area

\section{Introduction}

Hydropower is one of the few renewable and clean energy sources. According to the Thailand 15 year power development plan for 2008 to 2022 (Power Policy Bureau, 2010), the total hydropower potential from every region in Thailand is about $328 \mathrm{MW}$.

This power is generated from 3 different categories of hydropower plants: the Royal Irrigation Department (RID)'s water resources project about 168 MW, small hydropower contributes about $154 \mathrm{MW}$, and from very small hydropower plants, about $6 \mathrm{MW}$ of power. Among the regions in Thailand, the northern part of Thailand has a very high potential for small hydropower development due to its steep slope topography. However, the suitable sites for small hydropower development are usually in forested areas with legal limitations. Various types of forests present different levels of legal obstacles. There are many laws and regulations that prohibit project development such as the B.E. 2484 (1941) Forest Act, the Ministerial Regulations Number 16, B.E. 2498 (1955), the B.E. 2504 (1961) National Park Act, the B.E. 2535 (1992) Wildlife Reservation and Protection Act, and the B.E. 2507 (1964) National Reserved Forest Act. Therefore, the procedure required for permission is varied and is dependent on both the desired development and the forest in question. In the past, no one has summarized or categorized the means to develop projects in forested areas, especially for the case of hydropower and the case when project sites involve more than one type of forested regions.

The objectives of this research are to analyze the laws and regulations related to project development in forested areas and to summarize on a case by case basis in a way that is easily understood and accessible for others to use as a reference for other areas. The suggestions for policy adjustments with environmental friendly considerations are also discussed. The small 
hydropower development sites in the Ping and Wang river basins which are the two main river basins in the northern part of Thailand are used as case studies.

\section{Methodology}

Supriyasilp et al.( 2009a) have reviewed laws and regulations related to project development in forested area and have classified the forested areas into three groups based on type of regulations. Each law and regulation has a specific procedure.

The first type are those forests which are protected by law, such as state forests, national parks, wildlife conservation areas, no-hunting areas, national reserved forests, and environmental protection areas. The laws related to the forest in this type are 1) the B.E. 2484 Forest Act, 2) the Ministerial Regulations Number 16, B.E. 2498, 3) the B.E. 2504 National Park Act, 4) the B.E. 2535 Wildlife Reservation and Protection Act, 5) the B.E. 2507 National Reserved Forest Act. If the area involves the B.E. 2484 Forest Act or the Ministerial Regulations Number 16, B.E. 2498, then the project can be developed. If the area involves the other laws, then the project development in the area is prohibited. However, there is exception for the B.E. 2504 National Park Act and the B.E. 2507 National Reserved Forest Act. Under the article 19 of the B.E. 2504 National Park Act, the project or any activities can be done within the area if it is done under the cooperation with the national park. However, the benefit of the project should be used for the purpose of the national park only. For the areas which fall under the B.E. 2507 National Reserved Forest Act, the project can be done by the government agencies using the procedure under article 13.

The second type of forests is those provided by Cabinet Resolutions. This type of forest involves various laws and regulations regarding catchment quality and land use prohibition. By status, cabinet resolutions are not laws. But it is the government's policy that all governmental units abide by the cabinet resolutions. According to the Cabinet Resolution of 28 May B.E. 2528 (1985) which concerns the criteria for judging the quality of catchment and measures for land use (along the Ping and Wang Rivers), the area announced as the catchment quality class $1 \mathrm{~A}$ and $1 \mathrm{~B}$ is prohibited for all types of project development. This area is reserved as the source of the river. Regarding the Cabinet Resolution of 15 May B.E. 2533 (1990), which concerns permission to use land in the forest areas, the area defined as the conservation area (zone c) cannot be used by a private agency. A government agency can implement a project in the area but must do an environmental impact assessment first.

The third type of area include areas such as parks, arboretums, and state forestry plantations of all kinds including those commemorating the members of the royal family, areas in preparation to be national parks, wildlife breeding and protection areas and areas where hunting is prohibited.

The principles that should be kept in mind when considering the forested area with legal limitation can be summarized as follows.

1) If it is prohibited by law, with no provision for exception, go by the law. When time is needed in the process of annulling/invalidating the law, avoid using the disputed area altogether.

2) If the law has provision for exception, but there is cabinet resolution prohibiting permission, a move to make changes to the resolution must be done first. 


\section{Case studies and application}

\subsection{Study areas}

The Ping and Wang river basins are selected as case studies. The Ping river basin covers about five provinces namely Chiang Mai, Lamphun, Tak, Kamphaeng Phet, and Nakhon Sawan. It originates in the Pee Pan Nam mountain range in the Chiang Dao district, Chiang Mai province. After passing the town of Chiang Mai, it flows through the provinces of Lamphun, Tak, and Kamphaeng Phet. At the confluence with the Nan River at Nakhon Sawan (also named Paknam Pho in Thai) it forms the Chao Phraya River. The area of the Ping River Basin is approximately $34,856 \mathrm{~km}^{2}$. The total length is $740 \mathrm{~km}$. The Wang river basin is smaller than the Ping river basin. It covers most areas of the Lampang province. The watershed area is about $10,793.57 \mathrm{~km}^{2}$ with the total river length of $460 \mathrm{~km}$. The Wang River flows through Lampang province and meets the Ping River at Tak province.

\subsection{Potential hydropower development projects}

The National Research Council of Thailand (NRCT) has provided funding for the study of potential hydropower development in Thailand. According to the recent research on the study of potential sites for hydropower development in the Ping and Wang river basin (Supriyasilp et al., 2009b; Supriyasilp et al., 2010), there are 64 and 19 potential projects in Ping and Wang river basin, respectively. The Ping river basin has a much steeper slope than the Wang river basin and therefore, it has more potential projects than the Wang River Basin. Moreover, the very small projects which provide installed capacity less than $100 \mathrm{~kW}$ are neglected for the hydropower potential analysis in the Ping River Basin. For the Ping river basin, the overall electricity potential is about $211 \mathrm{MW}$ with annual power generation about $720 \mathrm{GWh}$. For the Wang River Basin, the electricity potential is about $6 \mathrm{MW}$ and the annual power generation is about $30 \mathrm{GWh}$.

The hydropower schemes in the studies of hydropower development in the Ping and Wang river basins are classified into three types: low head Q based (LHQB), waterway (WW), and dam with storage (DwS) or reservoir type. When analyzing the power capacity, amount of water flow and head of water are two major factors to be considered. The Q in LHQB type stands for discharge or amount of flow per unit of time. The head is a vertical change in elevation between the headwater level and the tail water level excluding loss. The LHQB type is usually applied when the head is low and the amount of flow is large such as in the lower reach and major tributary. The WW type is also called the diversion type or run-ofriver type, which part of water is diverted from the main stream to the facilitated channel through the penstock to the turbine. In DwS type, a dam is built to store river water as a reservoir. Following a specific operation rule, water may be released either to meet electricity needs or to maintain an appropriate reservoir level.

Supriyasilp et al. (2009b) has classified the potential sites for the analysis into 6 categories based on the available data and development practices in power generation evaluation. The details of each group are as described as follow.

Group I: The new sites in main river.

For the Ping River, there are many sub watershed and several tributaries. The major tributary usually gives large amount of flow with low head. Thus, the hydropower scheme in this group is the LHQB type. However, the hydropower development in this group is limited since Thai communities are usually situated along the river because the main occupation of the Thai people is agriculture. Even though, nowadays the way of life has changed to be more 
industrialized, the preference of a place for living is still near the river. Therefore, there are a lot of communities along the way of the Ping River. Only two potential sites were found in this group to avoid the serious impact on the communities. For the Wang River, there is no project under this group.

Group II: The existing reservoirs

There are several existing reservoirs in Thailand. Most of them are the responsibility of the Royal Irrigation Department (RID). These reservoirs are mainly used for irrigation. They are also considered for hydropower potential development in order to increase the value added of the water in the reservoir. There are three potential sites in each river basin that fall within this category. The hydropower scheme in this category is considered as DwS type.

Group III: The sites in previous studies

Several organizations related to the development of energy such as Electricity Generating Authority of Thailand (EGAT) have studied on the potential sites to develop hydropower projects. In the past, the large dam construction was usually obstructed by the people in the area and the non-government organizations (NGOs). The sites found in the previous studies are also considered in the study of Supriyasilp et al. (2009 and 2010) but need to be reanalyzed on the amount of flow and cost of construction in the engineering and economic aspects. The hydropower scheme in this group is DwS type. There are four sites in this category in the Ping river basin.

Group IV: The sites studied by the Department of Alternative Energy Development and Efficiency (DEDE)

There are 12 sites for the Ping river basin and no sites for the Wang river basin found in the study of the DEDE. Most sites in this group were located in minor tributaries which had a steep topography. All of them are WW type.

Group V: The sites in water organization's development plan.

The sites in this group are from the development plans of relevant water organizations such as the RID and the Department of Water Resources (DWR). The water resource development projects in these plans mainly aim for irrigation purposes. Thus, the analysis has been done under the concept of adding the power capacity to the projects and generating electricity as a by-product. This introduces the value added of the projects and makes the projects more feasible to develop. The hydropower scheme in this group is DwS type. There are 23 sites for the Ping river basin.

Group VI: The new sites from major tributaries

Apart from the sites in group I, the sites in this group have just explored and examined other than previous studies. The study process was started from the site selection. There are $9 \mathrm{WW}$ sites and 11 DwS sites found for Ping river basin, while there are $7 \mathrm{WW}$ sites and 9 DwS sites for Wang river basin.

\section{Discussion}

Table 1 shows the legal limitations for each potential site in the Ping and Wang river basin based on forested area type. For both river basins, none of the sites is within the forested area type 3. Most of the sites involve more than one type of forested area and more than one law in each forest type. The procedures are summarized in 6 categories as follows. Even though 
the categories are illustrated based on the Ping and Wang cases, they can be applied as the references for other project development in forested areas.

Category I: the site involves the area announced by the Cabinet Resolution concerning the catchment quality class $1 \mathrm{~A}$ and $1 \mathrm{~B}$. The resolution for that area has to be removed first before one can follow the steps to request use of that area for other laws.

Category II: the site involves the area announced by the Cabinet Resolution as zone C. The environmental impact assessment has to be done for the project development at that site. The process usually takes time.

Category III: the site involves the National Park Act. Under article 19 of the B.E. 2504 National Park Act, the project or any activities can be done within the area if it is done under the cooperation with the national park. However, the benefit of the project should be used for the purpose of the national park only.

Category IV: the site involves the Wildlife Protection Act. Project development in this area is prohibited.

Category V: the site involves the Reserved Forest Act. The project can be done by the government agencies using the procedure following article 13 of the Act.

Category VI: the site involves the Forest Act. The project can be done following the Ministerial Regulations Number 16, B.E. 2498. Therefore, if the project is in category VI only, the procedure is easiest among all categories.

Even though the technical aspects such as electricity generation is important, engineering and economics aspects, the socio-economics, environment, law and regulation, and stakeholder involvement aspects should also be taken into consideration. The sites in group 3 can provide the most installed capacity. However, large dams have to be constructed. This can cause a lot more impacts to the environment comparing to the DwS in other groups, which dam's size is much smaller. The sites in group 1 have low interest rate of return (IRR) and high electricity generating cost (Supriyasilp et al., 2009b). Therefore, the sites in group 1 and 3 are not preferred.

Among the groups, the sites in group 2 seem to be the most preferable due to less legal limitations. Also their environmental impacts are less than the other groups since they already have a reservoir. Group 5 involves less laws and regulation than group 4 and 6 . Therefore, they are more preferable. The sites in group 4 and 6 involve more than one type of forested area. There are two sites in the Ping river basin in Category IV, which is prohibited. Most of the sites involve with the Cabinet Resolution 1A (category I) and zone C (category II) together with either the National Park Act (category III) or the Reserved Forest Act (category $\mathrm{V})$. 
Table 1. Laws and regulations related to each potential site.

\begin{tabular}{|c|c|c|c|c|c|c|c|c|c|c|}
\hline \multirow[t]{2}{*}{$\begin{array}{l}\text { Site } \\
\text { no. }\end{array}$} & \multirow[t]{2}{*}{ Group } & \multirow[t]{2}{*}{$\begin{array}{c}\text { HP } \\
\text { scheme }\end{array}$} & \multirow{2}{*}{$\begin{array}{c}\text { Installed } \\
\text { capacity } \\
(\mathrm{kW})\end{array}$} & \multirow{2}{*}{$\begin{array}{c}\text { Annual } \\
\text { energy } \\
\text { production } \\
(G W h)\end{array}$} & \multicolumn{4}{|c|}{ Forest by laws } & \multicolumn{2}{|c|}{$\begin{array}{c}\text { Cabinet } \\
\text { resolution }\end{array}$} \\
\hline & & & & & $\begin{array}{l}\text { F. } \\
\text { A. }\end{array}$ & $\begin{array}{c}\text { NP. } \\
\text { A. }\end{array}$ & $\begin{array}{l}\text { WP. } \\
\text { A. }\end{array}$ & $\begin{array}{l}\text { RF. } \\
\text { A. }\end{array}$ & $\begin{array}{l}1 \mathrm{~A} / \\
1 \mathrm{~B}\end{array}$ & $\begin{array}{c}\text { Zone } \\
\text { C }\end{array}$ \\
\hline P1 & 1 & LHQB & 100 & 0.6 & & & & $\bullet$ & & \\
\hline $\mathrm{P} 2$ & 1 & LHQB & 700 & 4.3 & - & & & & & \\
\hline P3 & 2 & DwS & 2,000 & 6.1 & - & & & & & \\
\hline P4 & 2 & DwS & 110 & 0.8 & & & & - & & \\
\hline P5 & 2 & DwS & 257 & 2.1 & & & & - & & \\
\hline P6 & 3 & DwS & 77,000 & 104.5 & & & & - & - & - \\
\hline P7 & 3 & DwS & 26,000 & 55.1 & & & & - & - & - \\
\hline P8 & 3 & DwS & 8,000 & 58.6 & & & & - & - & - \\
\hline P9 & 3 & DwS & 8,000 & 25.9 & $\bullet$ & & & & & \\
\hline P10 & 4 & WW & 13,600 & 49.6 & & • & & - & - & - \\
\hline P11 & 4 & WW & 628 & 3.6 & & & & $\bullet$ & & \\
\hline $\mathrm{P} 12$ & 4 & WW & 930 & 4.1 & & & & $\bullet$ & - & $\bullet$ \\
\hline P13 & 4 & WW & 1,600 & 7.8 & & & & - & - & - \\
\hline P14 & 4 & WW & 90 & 3.8 & & & & $\bullet$ & & $\bullet$ \\
\hline P15 & 4 & WW & 1,051 & 5.3 & & & & $\bullet$ & - & $\bullet$ \\
\hline P16 & 4 & WW & 1,447 & 7.1 & & $\bullet$ & & $\bullet$ & - & - \\
\hline P17 & 4 & WW & 1,450 & 6.8 & & & & - & & - \\
\hline P18 & 4 & WW & 1,322 & 7.0 & & $\bullet$ & & $\bullet$ & & $\bullet$ \\
\hline P19 & 4 & WW & 164 & 0.8 & & $\bullet$ & & $\bullet$ & $\bullet$ & $\bullet$ \\
\hline P20 & 4 & WW & 760 & 3.8 & & $\bullet$ & & $\bullet$ & $\bullet$ & $\bullet$ \\
\hline P21 & 4 & WW & 417 & 2.1 & & & & $\bullet$ & $\bullet$ & $\bullet$ \\
\hline P22 & 5 & Plan DwS & 1,043 & 7.1 & & $\bullet$ & & $\bullet$ & $\bullet$ & $\bullet$ \\
\hline P23 & 5 & Plan DwS & 11,058 & 59.3 & & & & $\bullet$ & $\bullet$ & $\bullet$ \\
\hline P24 & 5 & Plan DwS & 2,218 & 9.3 & & & & $\bullet$ & & \\
\hline P25 & 5 & Plan DwS & 883 & 1.4 & $\bullet$ & & & & & \\
\hline P26 & 5 & Plan DwS & 1,413 & 2.0 & & & & $\bullet$ & & \\
\hline P27 & 5 & Plan DwS & 142 & 0.3 & & & & $\bullet$ & & \\
\hline P28 & 5 & Plan DwS & 1,457 & 2.0 & - & & & & & \\
\hline P29 & 5 & Plan DwS & 761 & 1.4 & & & & $\bullet$ & & \\
\hline P30 & 5 & Plan DwS & 674 & 1.3 & & & & $\bullet$ & & \\
\hline P31 & 5 & Plan DwS & 721 & 1.1 & & & & $\bullet$ & & \\
\hline P32 & 5 & Plan DwS & 333 & 1.2 & & & & $\bullet$ & & \\
\hline P33 & 5 & Plan DwS & 113 & 0.5 & $\bullet$ & & & & & \\
\hline P34 & 5 & Plan DwS & 982 & 8.6 & & $\bullet$ & & $\bullet$ & & \\
\hline P35 & 5 & Plan DwS & 129 & 0.9 & & - & & & & - \\
\hline P36 & 5 & Plan DwS & 2,495 & 8.2 & $\bullet$ & & & & & \\
\hline P37 & 5 & Plan DwS & 107 & 0.4 & $\bullet$ & & & & & \\
\hline P38 & 5 & Plan DwS & 169 & 0.5 & $\bullet$ & & & & & \\
\hline P39 & 5 & Plan DwS & 812 & 6.7 & & & & - & & \\
\hline P40 & 5 & Plan DwS & 99 & 0.4 & & $\bullet$ & & $\bullet$ & & \\
\hline P41 & 5 & Plan DwS & 429 & 1.5 & & & & - & & \\
\hline P42 & 5 & Plan DwS & 2,052 & 8.2 & & & & • & & \\
\hline P43 & 5 & Plan DwS & 5,026 & 43.8 & & $\bullet$ & & $\bullet$ & & $\bullet$ \\
\hline P44 & 5 & Plan DwS & 114 & 0.9 & & & & $\bullet$ & & \\
\hline
\end{tabular}


Table 2. Laws and regulations related to each potential site (con't).

\begin{tabular}{|c|c|c|c|c|c|c|c|c|c|c|}
\hline \multirow[t]{2}{*}{$\begin{array}{l}\text { Site } \\
\text { no. }\end{array}$} & \multirow[t]{2}{*}{ Group } & \multirow[t]{2}{*}{$\begin{array}{c}\text { HP } \\
\text { scheme }\end{array}$} & \multirow{2}{*}{$\begin{array}{c}\text { Installed } \\
\text { capacity } \\
(\mathrm{kW})\end{array}$} & \multirow{2}{*}{$\begin{array}{c}\text { Annual } \\
\text { energy } \\
\text { production } \\
\text { (GWh) }\end{array}$} & \multicolumn{4}{|c|}{ Forest by laws } & \multicolumn{2}{|c|}{$\begin{array}{c}\text { Cabinet } \\
\text { resolution }\end{array}$} \\
\hline & & & & & $\begin{array}{l}\text { F. } \\
\text { A. }\end{array}$ & $\begin{array}{c}\text { NP. } \\
\text { A. }\end{array}$ & $\begin{array}{l}\text { WP. } \\
\text { A. }\end{array}$ & $\begin{array}{l}\text { RF. } \\
\text { A. }\end{array}$ & $\begin{array}{l}1 \mathrm{~A} / \\
1 \mathrm{~B}\end{array}$ & $\begin{array}{c}\text { Zone } \\
\text { C }\end{array}$ \\
\hline P45 & 6 & DwS & 2,000 & 12.4 & & & & $\bullet$ & $\bullet$ & $\bullet$ \\
\hline P46 & 6 & DwS & 1,500 & 9.3 & & $\bullet$ & & $\bullet$ & $\bullet$ & $\bullet$ \\
\hline P47 & 6 & WW & 300 & 1.9 & & • & & • & & • \\
\hline P48 & 6 & DwS & 1,000 & 6.1 & & & & $\bullet$ & $\bullet$ & $\bullet$ \\
\hline P49 & 6 & WW & 600 & 3.6 & & & & $\bullet$ & $\bullet$ & $\bullet$ \\
\hline P50 & 6 & WW & 300 & 1.8 & & & & $\bullet$ & & $\bullet$ \\
\hline P51 & 6 & DwS & 1,100 & 6.7 & & & & $\bullet$ & $\bullet$ & • \\
\hline P52 & 6 & WW & 600 & 3.6 & & & & $\bullet$ & $\bullet$ & $\bullet$ \\
\hline P53 & 6 & WW & 300 & 1.8 & & & & $\bullet$ & $\bullet$ & $\bullet$ \\
\hline P54 & 6 & DwS & 1,000 & 6.1 & & & & $\bullet$ & $\bullet$ & $\bullet$ \\
\hline P55 & 6 & DwS & 5,300 & 32.2 & & & & $\bullet$ & $\bullet$ & $\bullet$ \\
\hline P56 & 6 & DwS & 300 & 1.8 & & & & $\bullet$ & & \\
\hline P57 & 6 & WW & 200 & 1.2 & & & & $\bullet$ & & $\bullet$ \\
\hline P58 & 6 & DwS & 1,800 & 10.8 & & & & $\bullet$ & $\bullet$ & $\bullet$ \\
\hline P59 & 6 & WW & 1,600 & 9.6 & & & & $\bullet$ & $\bullet$ & $\bullet$ \\
\hline P60 & 6 & DwS & 3,200 & 19.2 & & & & $\bullet$ & $\bullet$ & $\bullet$ \\
\hline P61 & 6 & WW & 2,500 & 15.0 & & & & $\bullet$ & $\bullet$ & $\bullet$ \\
\hline P62 & 6 & WW & 3,300 & 19.8 & & & & $\bullet$ & $\bullet$ & • \\
\hline P63 & 6 & DwS & 2,800 & 16.8 & & & - & & $\bullet$ & • \\
\hline P64 & 6 & DwS & 2,200 & 13.2 & & & • & & & • \\
\hline W1 & 6 & WW & 20 & 0.12 & • & & & & • & \\
\hline W2 & 6 & WW & 20 & 0.12 & & - & & • & • & • \\
\hline W3 & 6 & WW & 230 & 1.38 & & • & & • & • & • \\
\hline W4 & 6 & WW & 30 & 0.18 & & $\bullet$ & & $\bullet$ & $\bullet$ & $\bullet$ \\
\hline W5 & 6 & DwS & 200 & 1.19 & & • & & • & • & • \\
\hline W6 & 6 & DwS & 370 & 2.21 & & $\bullet$ & & $\bullet$ & $\bullet$ & • \\
\hline W7 & 6 & DwS & 170 & 1.01 & & $\bullet$ & & $\bullet$ & $\bullet$ & • \\
\hline W8 & 6 & DwS & 140 & 0.83 & & • & & $\bullet$ & • & • \\
\hline W9 & 6 & DwS & 10 & 0.06 & & • & & • & • & • \\
\hline W10 & 6 & DwS & 20 & 0.12 & & • & & • & • & • \\
\hline W11 & 6 & DwS & 20 & 0.12 & & • & & • & • & \\
\hline W12 & 6 & WW & 10 & 0.06 & & & & $\bullet$ & • & $\bullet$ \\
\hline W13 & 6 & DwS & 10 & 0.06 & & & & $\bullet$ & • & $\bullet$ \\
\hline W14 & 6 & WW & 50 & 0.3 & & & & • & • & • \\
\hline W15 & 6 & WW & 30 & 0.18 & & & & $\bullet$ & & • \\
\hline W16 & 6 & DwS & 10 & 0.06 & & • & & $\bullet$ & • & • \\
\hline W17 & 2 & DwS & 2,300 & 6.22 & & & & $\bullet$ & & $\bullet$ \\
\hline W18 & 2 & DwS & 2,200 & 15.92 & • & & & & & \\
\hline W19 & 2 & DwS & 50 & 0.07 & & & & • & & \\
\hline
\end{tabular}

F.A= Forest Act; NP.A.= National Park Act; WP.A.= Wildlife Protection Act;

RF.A= Reserved Forest Act; P1= site no. 1 in Ping river basin; W1=site no.1 in Wang river basin 


\section{Conclusion}

Legal matters present the main obstacle for small hydropower project development in the Northern Region of Thailand. The preferable site usually involves more than one type of forested areas. This paper has summarized the laws and regulations related to hydropower development in forested areas and has suggested the means to develop potential hydropower sites by classifying them into 6 categories. It is recommended that to promote the hydropower development, three issues have to be taken into consideration. First, the laws and regulations have to be systematically reformed so that they are consistent with each other and up to the country's present situation. Second, the issue about project ownership stated in the law has to be reconsidered. The community and private sector should be able to take part in the investment and receive benefits from selling electricity. Regarding the community's investment, people in the community would feel that they are the owner of the resources and as a result would have an incentive to take proper care of the resources. However, the regulation reform for this issue has to be done carefully by considering the concept of balancing the benefits of energy and the detriment to the environment. Lastly, the regulation limiting the use of electricity within the park area should be revised. The excess electricity from the park can then be used to support the national grid.

\section{Acknowledgement}

The authors would like to acknowledge the important support given by the National Research Council of Thailand (NRCT).

\section{References}

[1] Power Policy Bureau, Energy Policy and Planning Office, Ministry of Energy, Thailand. 25 Mar 2010.

[2] Forest Act B.E. 2484, Royal Thai Government Gazette 58, 73, 1941.

[3] Ministerial Regulations Number 16, B.E. 2498, Ministry of Natural Resources and Environment, Thailand, 1955.

[4] National Park Act B.E. 2504, Royal Thai Government Gazette 78, 80, 1961.

[5] Wildlife Reservation and Protection Act B.E. 2535, Royal Thai Government Gazette 109, 15, 1992.

[6] National Reserved Forest Act B.E. 2507, Royal Thai Government Gazette 81, 38, 1964.

[7] T. Supriyasilp, K. Pongput, C. Robkob, J. Ruangvichathorn, T. Boonyasirikul, and S. Boonyanupong, Law and Hydropower Project Development in Forested Areas, National Research Council Journal, the Special Edition for Renewable Energy, 2009a, pp. 28-39.

[8] Cabinet Resolution of 28 May B.E. 2528, 1985.

[9] Cabinet Resolution of 15 May B.E. 2533, 1990.

[10] T. Supriyasilp, K. Pongput, and T. Boonyasirikul, Hydropower Development Priority Using MCDM Method. Energy Policy 37, 5, 2009b, pp. 1866 -1875.

[11] T. Supriyasilp, K. Pongput, T. Boonyasirikul, S. Boonyanupong, C. Tuksaudom, and R. Yongprayun, the Study of Potential and Regulation Issues for Hydropower Development in Wang River Basin, NRCT report, 2010. 